\title{
Nutritional status of healthy, active, Chinese elderly
}

\author{
By JEAN WOO,${ }^{1}$ S. C. HO, ${ }^{2}$ S. P. B. DONNAN ${ }^{2}$ AND R. SWAMINATHAN ${ }^{3}$ \\ Departments of ${ }^{1}$ Medicine, ${ }^{2}$ Community Medicine, and ${ }^{3}$ Chemical Pathology, \\ Chinese University of Hong Kong, Shatin, N.T., Hong Kong
}

\author{
(Received 10 November 1987 - Accepted 26 January 1988)
}

\begin{abstract}
1. Anthropometric indices are presented for $\mathbf{4 0 2}$ healthy Chinese elderly subjects leading an active life in the community in Hong Kong.

2. Women had higher body-mass index (weight/height ${ }^{2}$ ) and body fat, while fat-free mass, arm-muscle circumference and corrected arm-muscle area were higher in men. Body-mass index, fat-free mass, arm-muscle circumference and corrected arm-muscle area did not decline with age. Total body fat was lower in women aged 75 years and above compared with those aged $60-64$ years.

3. All values were lower than those for elderly Caucasians. A different criteria for severe wasting malnutrition among elderly Chinese should be established.
\end{abstract}

Assessment of nutritional status is important in the elderly, partly because of the low to moderate prevalence of possible deficiencies in both institutionalized and non-institutionalized groups, and partly because of the association between nutrition and many of the chronic diseases commonly affecting the elderly (McGandy, 1985). Anthropometry is an easy, cheap and non-invasive method of assessing nutritional status, and correlations have been found between anthropometric and biochemical indices of nutrition (Morgan et al. 1986). Anthropometric indices have also been reported to be of prognostic value in predicting mortality (Friedman et al. 1985). Reference ranges for adults (Bishop et al. 1981; Frisancho, 1981; Birkbeck, 1983) and particularly for the elderly (Burr \& Phillips, 1984; Morgan et al. 1986) are available for Caucasians. Since there is little information on anthropometric indices in the Chinese elderly, reference ranges need to be established from a healthy, active population. We studied 402 subjects over 60 years of age to provide a frame of reference for the elderly Chinese in this population. The association between anthropometric measurements and some biochemical indices of nutrition is also examined.

\section{SUBJECTS AND METHODS}

A group of 158 men and 244 women (mean age $70 \cdot 6$ (SD 4.5), range 6086 years), living in sheltered housing were studied. The sheltered housing complex consists of flats shared by up to six elderly people, interspersed with flats occupied by other members of the public. The criteria for entry into sheltered housing is that the applicant should be capable of selfcare, able to lead a normal active life, but unable to buy their own accommodation as their income is derived mainly from social welfare. The response rate was $96 \%$, the reason for refusal being fear of venesection, which formed part of the survey. Of the respondents $11 \%$ were still employed, mainly as unskilled and service workers. Among those who were not employed, $84.8 \%$ were retired unskilled workers.

The study took place from June to November in 1986. All measurements, interviews and venesection were done in a geriatric day hospital. Height and weight were measured in indoor clothing without shoes, using a standing scale with height measurement attachment. Arm circumference was measured at the mid-point between the acromion and olecranon process. Biceps and triceps skinfold thickness were measured with Holtain calipers at the 
same point. The average of three readings was used. All measurements were done by two registered nurses. No test of interobserver variation was performed.

Venous blood $(20 \mathrm{ml})$ was collected in a heparinized container for biochemical measurements. Retinol-binding protein and pre-albumin were determined by an immunotrurbidimetric method with polyclonal antibodies automated on Cobas Bio (Roche Diagnostic, Basle, Switzerland; Cheung et al. 1987, Hamlin \& Pankowsky, 1987). The polyclonal antibodies were obtained from Dako Ltd (High Wycombe, Bucks.). Albumin was measured on Parallel (American Monitor, Indianapolis) according to the manufacturer's manual. Body-mass index (BMI) was derived from weight $(\mathrm{kg}) / \mathrm{height}^{2}\left(\mathrm{~m}^{2}\right)$. Total body fat and fat-free mass were calculated according to Durnin \& Womersley (1974):

$$
\text { Total body fat }=\left(\frac{4.95}{(C-M) \times \log \text { skinfold }}-4.50\right) \times \text { body-weight, }
$$

where $C$ and $M$ are regression-equation constants for the estimation of body density from the logarithm of skinfold thickness, $C$ being 1.1185 for men and 1.1226 for women, $M$ being 0.0683 for men and 0.0710 for women; log skinfold is $\log$ (biceps + triceps skinfold thickness; $\mathrm{mm}$ ) and fat-free mass is body-weight - total body fat.

Arm-muscle circumference (AMC) was derived from the equation:

$$
\text { AMC }(\mathrm{c})=\operatorname{arm} \text { circumference }(\mathrm{cm})-\frac{\pi}{10} \times \text { triceps skinfold thickness }(\mathrm{mm}) \text {. }
$$

Corrected arm-muscle area (CAMA), a measurement of important prognostic value for severe wasting malnutrition in the elderly (Friedman et al. 1985) was calculated using the following equations (Heymsfield et al. 1982):

$$
\begin{aligned}
& \text { Male: CAMA }\left(\mathrm{cm}^{2}\right)=\frac{(\mathrm{AMC})^{2}}{4 \pi}-10, \\
& \text { Female: CAMA }\left(\mathrm{cm}^{2}\right)=\frac{(\mathrm{AMC})^{2}}{4 \pi}-6.5 .
\end{aligned}
$$

Results were analysed by a standard computer program (Statistical Analysis System). The following variables: BMI, total body fat, fat-free mass, AMC and CAMA were examined. Intact and log-transformed values were analysed for departures from normal Gaussian distribution.

The results are given as percentiles (25th-75th) for four age-groups in men and women, and also as the mean and standard deviation for each age-group, and for all male and female subjects. Student's $t$ test was used to detect differences in mean values between male and female subjects, and one-way analysis of variance (ANOVA) was used to assess variation of mean values between different age-groups in males and females. In calculating the reference range for each variable, after excluding any values that may be less than or greater than 3 SD from the mean, values were ranked in ascending order and the $95 \%$ confidence interval obtained by excluding the first and last $2 \cdot 5 \%$. Pearson's correlation matrix was used to determine associations of CAMA with plasma albumin, pre-albumin, retinol-binding protein, transferrin, fat-free mass and total body fat.

The distribution of BMI, AMC and CAMA in women and CAMA in men was Gaussian. After logarithmic transformation, the distribution of all variables conformed to normal. Tables 1-5 show the percentiles for the indices in men and women according to four age- 
Table 1. Percentiles for body-mass index (weight/height ${ }^{2}$ ) of active, healthy, Chinese elderly

\begin{tabular}{|c|c|c|c|c|}
\hline \multirow[b]{2}{*}{ Age (years) } & \multirow[b]{2}{*}{ No. } & \multicolumn{3}{|c|}{ Body-mass index $\left(\mathrm{kg} / \mathrm{m}^{2}\right)$} \\
\hline & & $25 \mathrm{th}^{*}$ & $50 \mathrm{th}^{*}$ & 75th* \\
\hline \multicolumn{5}{|l|}{ Men } \\
\hline $60-64$ & 20 & $19 \cdot 88$ & 21.97 & $24 \cdot 22$ \\
\hline $65-69$ & 58 & $18 \cdot 61$ & 21.46 & $23 \cdot 23$ \\
\hline $70-74$ & 64 & $19 \cdot 20$ & $21 \cdot 25$ & $24 \cdot 12$ \\
\hline $75+$ & 18 & $18 \cdot 81$ & $21 \cdot 17$ & 24-02 \\
\hline \multicolumn{5}{|l|}{ Women } \\
\hline $60-64$ & 26 & 21.63 & $24 \cdot 28$ & $26 \cdot 45$ \\
\hline $65-69$ & 80 & $19 \cdot 64$ & $22 \cdot 15$ & $25 \cdot 56$ \\
\hline $70-74$ & 95 & $19 \cdot 44$ & $22 \cdot 51$ & 25.09 \\
\hline $75+$ & 42 & 20.68 & $22 \cdot 32$ & $25 \cdot 15$ \\
\hline
\end{tabular}

* Percentiles.

Table 2. Percentiles for total body fat of active, healthy, Chinese elderly

\begin{tabular}{|c|c|c|c|c|}
\hline \multirow[b]{2}{*}{ Age (years) } & \multirow[b]{2}{*}{ No. } & \multicolumn{3}{|c|}{ Total body fat $(\mathrm{kg})$} \\
\hline & & 25 th* $^{*}$ & $50 \operatorname{th}^{*}$ & 75 th $^{*}$ \\
\hline \multicolumn{5}{|l|}{ Men } \\
\hline $60-64$ & 20 & $12 \cdot 81$ & $18 \cdot 30$ & 21.86 \\
\hline $65-69$ & 57 & 11.97 & $14 \cdot 66$ & 18.65 \\
\hline $70-74$ & 64 & $12 \cdot 80$ & $15 \cdot 14$ & $19 \cdot 54$ \\
\hline $75+$ & 18 & $12 \cdot 71$ & 14.84 & 20.89 \\
\hline \multicolumn{5}{|l|}{ Women } \\
\hline $60-64$ & 26 & $15 \cdot 19$ & $21 \cdot 23$ & $23 \cdot 33$ \\
\hline $65-69$ & 80 & $12 \cdot 87$ & 16.66 & $20-40$ \\
\hline $70-74$ & 95 & $12 \cdot 78$ & 16.00 & 20.95 \\
\hline $75+$ & 42 & 12.90 & $16 \cdot 72$ & $20 \cdot 44$ \\
\hline
\end{tabular}

* Percentiles.

Table 3. Percentiles for fat-free mass of active, healthy, Chinese elderly

\begin{tabular}{|c|c|c|c|c|}
\hline \multirow[b]{2}{*}{ Age (years) } & \multirow[b]{2}{*}{ No. } & \multicolumn{3}{|c|}{ Fat-free mass $(\mathrm{kg})$} \\
\hline & & $25 \mathrm{th}^{*}$ & $50 \operatorname{th}^{*}$ & $75 \mathrm{th}^{*}$ \\
\hline \multicolumn{5}{|l|}{ Men } \\
\hline 60-64 & 20 & $34 \cdot 44$ & 38.47 & 43.68 \\
\hline $65-69$ & 57 & 35.23 & $39 \cdot 75$ & $44 \cdot 60$ \\
\hline $70-74$ & 64 & $35 \cdot 70$ & $38 \cdot 48$ & 42.08 \\
\hline $75+$ & 18 & $33 \cdot 34$ & $40 \cdot 79$ & $43 \cdot 31$ \\
\hline \multicolumn{5}{|l|}{ Women } \\
\hline $60-64$ & 26 & 30.68 & 33.99 & $36 \cdot 32$ \\
\hline $65-69$ & 80 & $29 \cdot 38$ & 31.96 & 36.59 \\
\hline $70-74$ & 95 & 28.70 & 32.03 & 36.06 \\
\hline $75+$ & 42 & $30 \cdot 13$ & 33.25 & $36 \cdot 17$ \\
\hline
\end{tabular}

* Percentiles. 
Table 4. Percentiles for arm-muscle circumference of active, healthy, Chinese elderly

\begin{tabular}{|c|c|c|c|c|}
\hline \multirow[b]{2}{*}{ Age (years) } & \multirow[b]{2}{*}{ No. } & \multicolumn{3}{|c|}{ Arm-muscle circumference $(\mathrm{cm})$} \\
\hline & & $25 \operatorname{th}^{*}$ & 50 th $^{*}$ & $75 \mathrm{th}^{*}$ \\
\hline \multicolumn{5}{|l|}{ Men } \\
\hline $60-64$ & 20 & $20 \cdot 52$ & $21 \cdot 87$ & $23 \cdot 47$ \\
\hline $65-69$ & 58 & $20 \cdot 43$ & $22 \cdot 79$ & $24 \cdot 01$ \\
\hline $70-74$ & 64 & $20 \cdot 86$ & 22.03 & $23-29$ \\
\hline $75+$ & 18 & $19 \cdot 48$ & $22 \cdot 27$ & $22 \cdot 82$ \\
\hline \multicolumn{5}{|l|}{ Women } \\
\hline 60-64 & 26 & $19 \cdot 39$ & $20 \cdot 96$ & $22 \cdot 27$ \\
\hline $65-69$ & 80 & 18.66 & $19 \cdot 86$ & $21 \cdot 39$ \\
\hline $70-74$ & 95 & $18 \cdot 70$ & $20 \cdot 20$ & $21 \cdot 58$ \\
\hline $75+$ & 42 & 19.09 & $20 \cdot 39$ & 21.86 \\
\hline
\end{tabular}

* Percentiles.

Table 5. Percentiles for corrected arm-muscle area of active, healthy, Chinese elderly

\begin{tabular}{|c|c|c|c|c|}
\hline \multirow[b]{2}{*}{ Age (years) } & \multirow[b]{2}{*}{ No. } & \multicolumn{3}{|c|}{ Corrected arm-muscle area $\left(\mathrm{cm}^{2}\right)$} \\
\hline & & $25 \mathrm{th}^{*}$ & $50 \mathrm{th}^{*}$ & 75 th $^{*}$ \\
\hline \multicolumn{5}{|l|}{ Men } \\
\hline $60-64$ & 20 & $23 \cdot 52$ & $28 \cdot 05$ & 33.83 \\
\hline $65-69$ & 58 & $23 \cdot 21$ & $31 \cdot 32$ & 35.87 \\
\hline $70-74$ & 64 & $24 \cdot 62$ & 28.63 & $33 \cdot 15$ \\
\hline $75+$ & 18 & $20 \cdot 20$ & $29 \cdot 45$ & $31 \cdot 42$ \\
\hline \multicolumn{5}{|l|}{ Women } \\
\hline $60-64$ & 26 & $23 \cdot 41$ & $28 \cdot 46$ & 32.98 \\
\hline $65-69$ & 80 & $21 \cdot 21$ & $24 \cdot 88$ & $29 \cdot 90$ \\
\hline $70-74$ & 95 & $21 \cdot 34$ & 25.98 & $30 \cdot 54$ \\
\hline $75+$ & 42 & $22 \cdot 49$ & $26 \cdot 58$ & $31 \cdot 52$ \\
\hline
\end{tabular}

* Percentiles.

groups. Table 6 shows the means (and SD) of these indices by age and sex. There was no significant variation with age for any of these indices in men or women, using ANOVA. However, women aged 75 years and over had a significantly lower total body fat compared with those aged 60-64 years $(P<0.05$, Student's $t$ test). Fat-free mass, AMC and CAMA were higher in men than in women $(P<0.001$, Student's $t$ test), while BMI and total body fat were higher in women ( $P<0.001, P<0.05$ respectively, Student's $t$ test) (Table 7). The mean, with the $95 \%$ confidence interval, is provided for each variable for men and women (Table 7), and may be used as reference ranges for this population.

Since CAMA has been considered an accurate indication of protein status (Friedman, 1986), we examined its correlation with fat-free mass and biochemical indices of protein status (plasma albumin, pre-albumin, retinol-binding protein). A significant correlation was found between CAMA and fat-free mass $(r 0.68, P<0.001)$ (Fig. 1), CAMA and plasma pre-albumin $(r 0.20, P<0.001$ (Fig. 2$)$, and CAMA and plasma retinol-binding protein $(r 0 \cdot 16, P<0 \cdot 001)$. No correlation was found with plasma albumin. 
Nutritional status of Chinese elderly

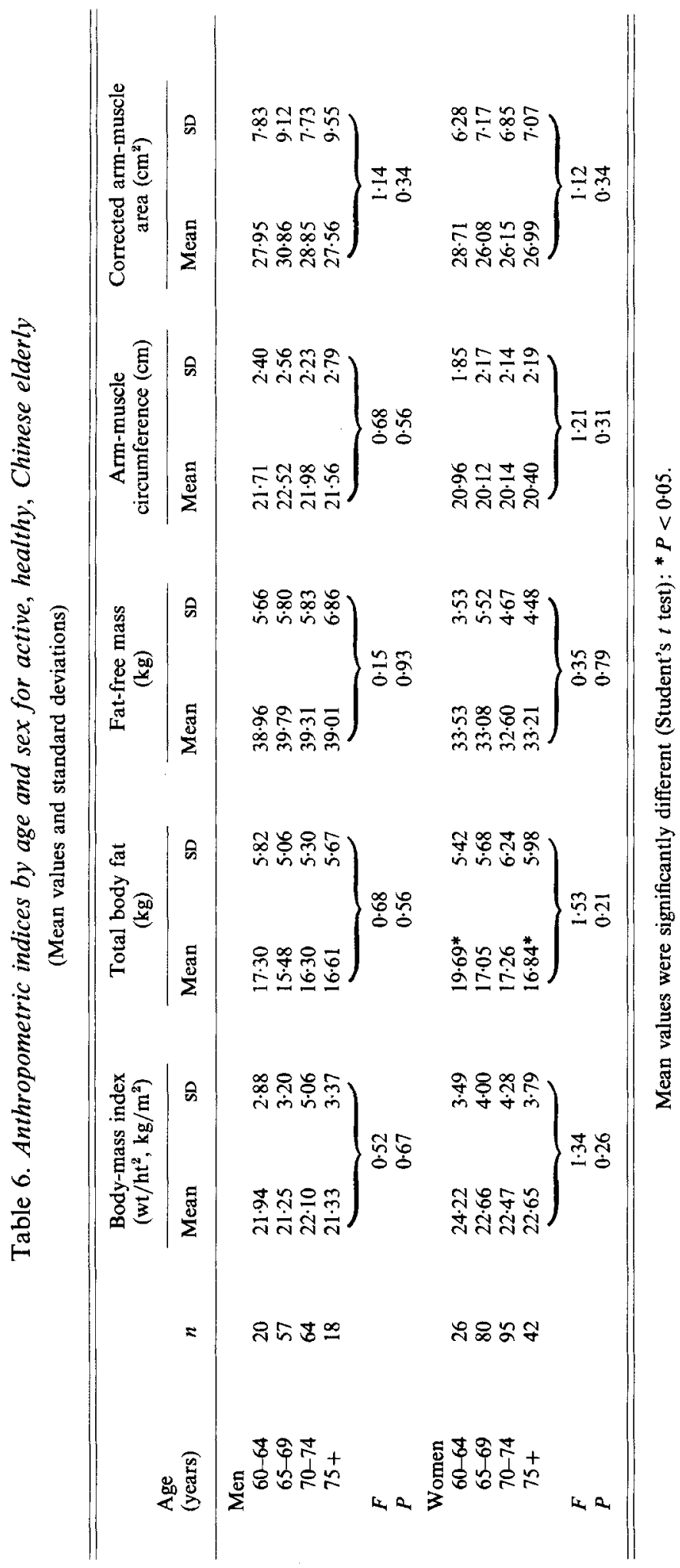




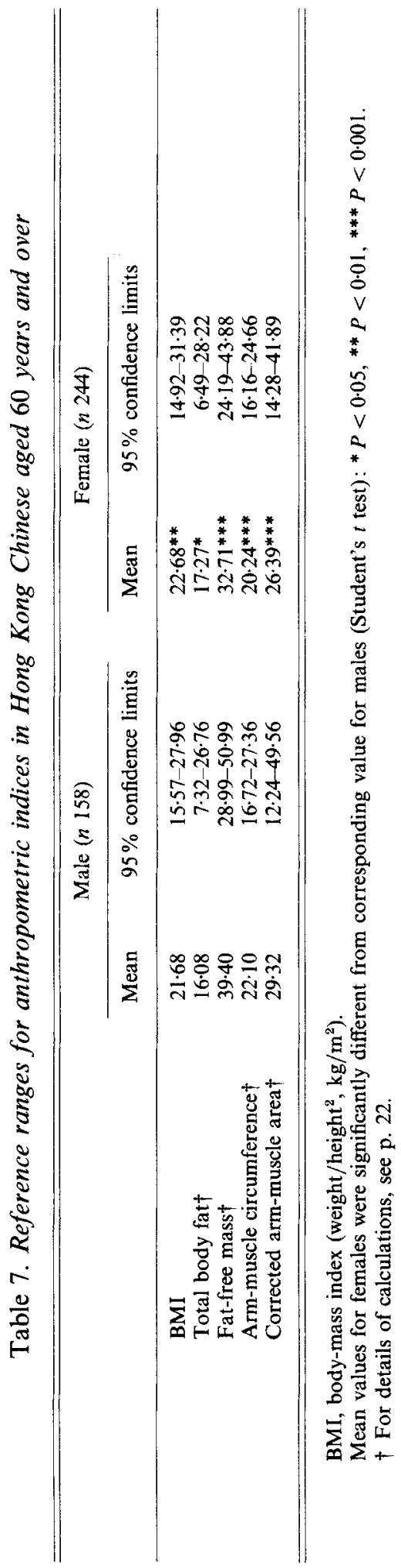




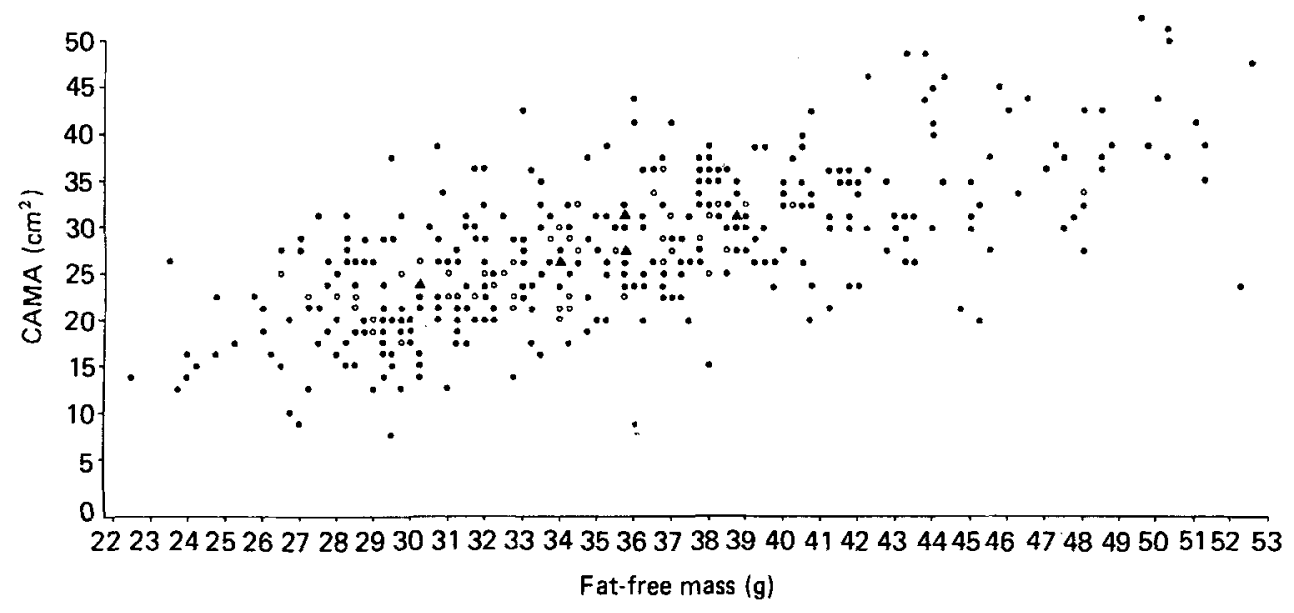

Fig. 1. Relation between corrected arm-muscle area (CAMA) and fat-free mass in active, healthy, Chinese elderly. For details of calculations, see p. 22. (O), One observation; $(O)$, two observations; $(\mathbf{A})$, three observations.

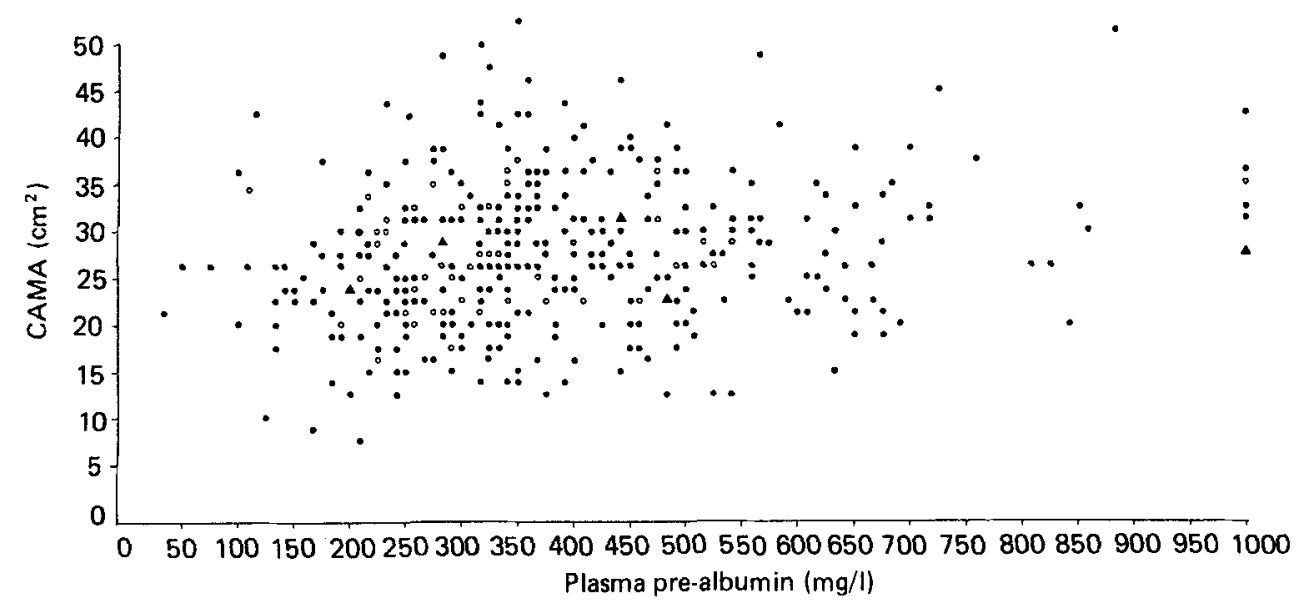

Fig. 2. Relation between corrected arm-muscle area (CAMA) and plasma pre-albumin in active, healthy, Chinese elderly. For details of calculations, see p. 22. (O), One observation; (O), two observations;

(A), three observations.

\section{DISCUSSION}

Although our values are derived from a cluster sample of the elderly living in sheltered housing, reference values obtained may apply to the rest of the elderly population as their socio-economic status and nutritional intake are representative of a large section of the elderly population in Hong Kong. Their dietary intake and anthropometric measurements are similar to those in another cohort study of 600 elderly subjects living with relatives or friends (S. C. Ho, S. P. B. Donnan and A. Sham, unpublished results). Their socioeconomic background can be considered representative of at least half the population in Hong Kong, as $96 \%$ belonged or had belonged to occupational group 7 (Hong Kong Census, Census and Statistics Dept., 1981), which consists of production and related 
workers, labourers and drivers. Of the working population in Hong Kong $50 \%$ belong to this group.

Protein depletion is reflected by muscle wasting, which can be assessed by fat-free-mass estimation. The calculation of fat-free mass is complicated, and requires weighing. CAMA is a simpler measurement, requiring only mid-arm circumference and triceps skinfold thickness for the calculation. Its use is particularly relevant in institutions where patients may be bedridden and difficult to weigh. It correlates very well with fat-free mass (Fig. 1) and also with biochemical indices of protein status such as pre-albumin and retinol-binding protein. Hence it is important to establish reference ranges for CAMA in the elderly.

Racial differences in anthropometric measurements are not unexpected. For example, the indices for Caucasians and Maoris living in New Zealand are quite different (Birkbeck, 1983). The BMI in elderly Chinese is lower than in elderly Caucasians over 65 years of age in the UK (Burr \& Phillips, 1984), Maori and Caucasian subjects aged 50-64 years in New Zealand (Birkbeck, 1983) and elderly Scandinavians over 70 years in Sweden (Steen et al. 1977). The 50th percentile value for the Chinese elderly falls on the 25 th percentile of the BMI for UK elderly (Burr \& Phillips, 1984). Our population had a sightly lower energy intake (J. Woo, S. C. Ho, N. Tsao and S. P. B. Donnan, unpublished results) compared with Caucasian studies, being 84 and $94 \%$ of the intake reported for Scandinavian men and women respectively (Steen et al. 1977). However, their protein intake was remarkably similar to the studies described previously (about $60 \mathrm{~g} / \mathrm{d}$ ). Total body fat, fat-free mass, AMC and CAMA were all lower than values for the UK elderly (Burr \& Phillips, 1984; Morgan et al. 1986). Consequently the diagnostic criterion of CAMA $\leqslant 16.0 \mathrm{~cm}^{2}$ in men or $\leqslant 16.9 \mathrm{~cm}^{2}$ in women for severe wasting malnutrition (Friedman, 1986) is unlikely to apply to elderly Chinese, as these values fall within the reference range for a healthy active population. A different criterion would seem appropriate for elderly Chinese subjects.

Unlike the study of Burr \& Phillips (1984), we did not observe any age-related decline in BMI and arm-muscle area. Lower total body fat in the older age group was only seen in women, when the 60-64 year age-group was compared with those 75 years and above.

\section{REFERENCES}

Birkbeck, J. A. (1983). A Report to the National Heart Foundation of New Zealand on the National Diet Survey 1977, 2nd ed. New Zealand University of Otago.

Bishop, C. W., Bowen, D. E. \& Ritchley, S. J. (1981). American Journal of Clinical Nutrition 34, $2530-2539$.

Burr, M. L. \& Phillips K. M. (1984). British Journal of Nutrition 51, 165-169.

Census and Statistics Dept. (1981) Hong Kong Census. Main Report, vol. 1. Hong Kong: Hong Kong Government.

Cheung, C. K., Swaminathan, R. \& Cockram, C. (1987). Clinical Chemistry 33, (6), 1033.

Durnin, J. V. G. A. \& Womersley, J (1974). British Journal of Nutrition 32, 77-97.

Friedman, P. J. (1986). In Recent Advances in Clinical Nutrition pp. 416-417 [M. L. Wahlquist and A. S. Truswell, editors]. London: John Libbey \& Co. Ltd.

Friedman, P. J., Campbell, A. J. \& Caradoc-Davies, T. H. (1985). Age and Ageing 14, 149-154.

Frisancho, A. R. (1981). American Journal of Clinical Nutrition 34, 2540-2545.

Hamlin, C. R. \& Pankowsky, D. A. (1987). Clinical Chemistry 33, $144-146$.

Heymsfield, S. B., McManus, C., Smith, J., Stevens, V. \& Nixon, D. W. (1982). American Journal of Nutrition 36, 680-690.

McGandy R. B. (1985). In Practical Geriatric Medicine, pp. 43-50 [A. N. Exton-Smith and M. E. Weksler, editors]. Edinburgh: Churchill Livingstone.

Morgan, D. B., Newton, H. M. V., Schorah, C. J., Jewitt, M. A., Hancock, M. R. \& Hullin, R. P. (1986). Age and Ageing 15, 65-76.

Steen, B., Isaksson, B. \& Svanborg, A. (1977). Acta Medica Scandinavia 611, Suppl. 39-86. 